\title{
A welcome to our new Editorial Board
}

\author{
Alan Mathios ${ }^{1}$ - Hans Micklitz ${ }^{2}$ - Lucia Reisch ${ }^{3}$. \\ John Thøgersen ${ }^{4} \cdot$ Christian Twigg-Flesner $^{5}$
}

Received: 30 November 2015 / Accepted: 1 December 2015 /

Published online: 12 December 2015

(C) Springer Science+Business Media New York 2015

One of the great strengths of the Journal of Consumer Policy has been the involvement of many of the world's leading scholars from the fields of Law, Economics and Behavioural Sciences on our Editorial Board. Members of the Editorial Board are crucial in facilitating the Editors' desire to maintain high standards of scholarly excellence in the work we publish, and we are extremely grateful for the invaluable work of our Editorial Board in contributing both to our rigorous peer-review system and to the strategic development of the Journal.

Every 5 years, the $J C P$ undertakes a full review of the membership of its Editorial Board, both to allow time-served members a well-deserved break, and to add new talent driving the development of consumer policy scholarship. We are delighted to announce to the readership of the Journal of Consumer Policy that we have once again been able to add an impressive list of outstanding scholars to our Board, as well as persuading many highly esteemed colleagues to stay with us for another 5-year term.

We are very grateful to those board members who have served their terms and now leave the Board with our appreciation. And we are delighted to welcome the newcomers, whose experience across the breadth of disciplines related to consumer policy will allow us to remain at the forefront of publishing original scholarship in these areas.

The new Board represents scholars from 18 countries from around the globe and many of the finest academic institutions all over the world. A full list of the Editorial Board members 2016-2020 can be found on the inside cover of the Journal as well as on the website.

The editors look forward to working with our new Editorial Board over the coming years.

Christian Twigg-Flesner

c.twigg-flesner@hull.ac.uk

1 Cornell University, New York, USA

2 European University Institute, Florence, Italy

3 Copenhagen Business School, Copenhagen, Denmark

4 Aarhus University, Aarhus, Denmark

5 University of Hull, Hull, UK 